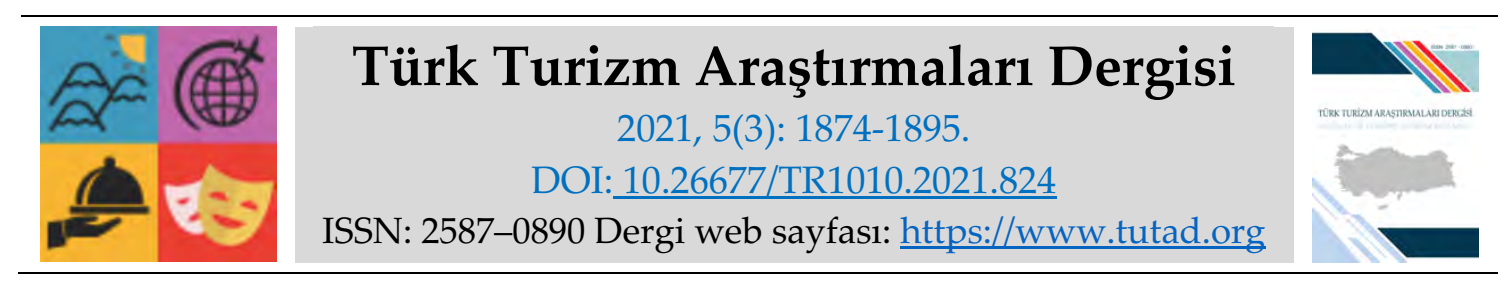

ARASTTIRMA MAKALESI

\title{
Yerel Halkın Turizm Gelişimine Yönelik Tutumu: Çorum İli Örneği
}

Dr. Öğr. Üyesi Emre AYKAÇ, İstanbul Gelişim Üniversitesi, Güzel Sanatlar Fakültesi, İstanbul, e-posta: emreaykac1@hotmail.com

ORCID: https://orcid.org/0000-0003-1700-0122

Dr. Mehmet TEKELİ, Bağımsız Araştırmacı, Karaman, e-posta: tekelimehmet@hotmail.com

ORCID: https://orcid.org/0000-0002-6069-4740

Öz

Bu araştırmanın temel amacı Çorum ili yerel halkının henüz emekleme aşamasında olan ve birçok alternatif türlere sahip, turizm olgusuna ve faaliyetlerine yönelik tutumunun ortaya koyulmasıdır. Bu doğrultuda uygulamalı bir nitelik taşıyan araştırmanın evrenini Çorum yerel halkı oluşturmaktadır. Araştırmada evrenin tümüne ulaşma şansı zor olduğundan örneklem alma yoluna gidilmiştir. Araştırma kapsamında belirlenen örneklemden verilerin toplanmasında anket tekniği kullanılmıştır. Verilerin analizinde betimsel analizlerden, bağımsız örneklem t-testi, anova testi ve tukey testlerinden yararlanılmıştır. Analizler sonucunda ekonomik, sosyal ve çevresel bakımdan bazı demografik özelliklere göre turizme yönelik tutumlarda farklılıkların olduğu sonucuna ulaşılmıştır. Ayrıca elde edilen bulgular doğrultusunda, Çorum yerel halkının yüksek düzeyde turizm gelişimine yönelik olumlu tutuma sahip olduğu tespit edilmiştir.

Anahtar Kelimeler: Yerel Halkın Tutumu, Turizm Gelişimi, Çorum, Alacahöyük, Hattuşaş (Boğazkale).

Makale Gönderme Tarihi: 21.06.2021

Makale Kabul Tarihi: 05.09.2021

\section{Önerilen Atıf:}

Aykaç, E. ve Tekeli, M. (2021). Yerel Halkın Turizm Gelişimine Yönelik Tutumu: Çorum İli Örneği, Türk Turizm Araştırmaları Dergisi, 5(3): 1874-1895.

(c) 2021 Türk Turizm Araştırmaları Dergisi. 


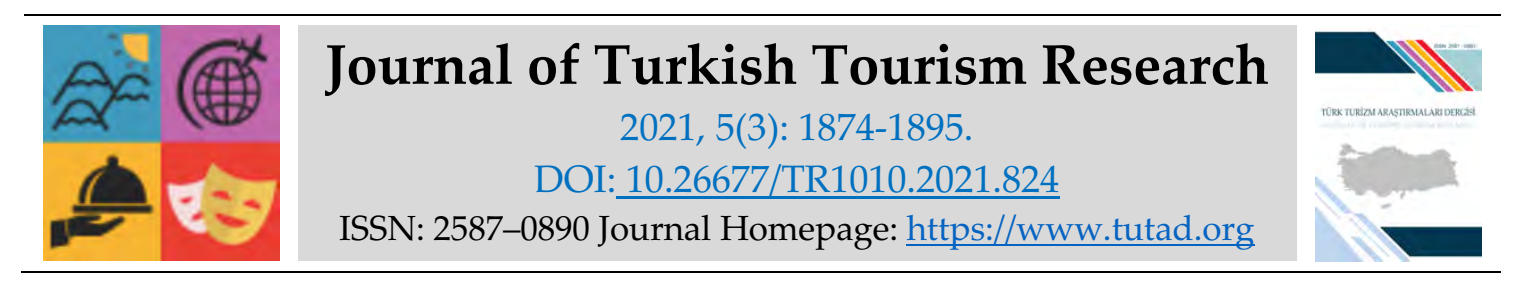

\title{
$\underline{\text { RESEARCH PAPER }}$
}

\section{The Attitude of Local People towards Tourism Development: The Case of Çorum Province}

Assistant Prof. Dr. Emre AYKAÇ, İstanbul Gelişim University, Faculty of Fine Arts, İstanbul,: emreaykac1@hotmail.com ORCID: https://orcid.org/0000-0003-1700-0122

Dr. Mehmet TEKELİ, Independent Scientist, Karaman, e-mail: tekelimehmet@hotmail.com ORCID: https://orcid.org/0000-0002-6069-4740

\begin{abstract}
The main purpose of this research is to reveal the perspective of the local people of Çorum province, which is still in its infancy and has many alternative types, towards the phenomenon of tourism and its activities. In this direction, the population of the research, which has an applied nature, is the local people of Çorum. Since the chance of reaching the whole universe is difficult in the research, the sampling method was used. The survey technique was used to collect data from the sample determined within the scope of the research. Descriptive analysis, independent sample t-test, Anova test, and Tukey tests were used in analyzing the data. As a result of the analysis, it has been concluded that there are differences in attitudes towards tourism according to some demographic characteristics in economic, social, and environmental terms. Besides, in line with the findings obtained, it was determined that the local people of Çorum have a positive attitude towards tourism development at a high level.
\end{abstract}

Keywords: Attitude of Local People, Tourism Development, Çorum, Alacahöyük, Hattuşaş (Boğazkale).

Received: 21.06 .2021

Accepted: 05.09.2021

\section{Suggested Citation:}

Aykaç, E. and Tekeli, M. (2021). The Attitude of Local People towards Tourism Development: The Case of Çorum Province, Journal of Turkish Tourism Research, 5(3): 1874-1895.

(C) 2021 Türk Turizm Araştırmaları Dergisi. 


\section{Gíriş}

Turizm olgusu ekonomik, sosyal ve çevresel faktörler temelinde çok boyutlu dinamik bir süreçtir. Turizm faaliyetleri ve buna ilişkin yerel halkın tutum düzeyinin de bu sürece etki eden temel faktörlerden biri olduğu düşünülmektedir. Ev sahibi bölgenin turizmden genel beklentisini karşılaması, en temelde bölgenin sahip olduğu hizmet kalitesi, çekicilik, reklam, tanıtım ve diğer unsurların gücü ile bağlantılıdır. Ancak ilgili paydaşların sorumluluklarının yanı sıra yerel halkın bölgedeki turizmin gelişimine destek olması da önemli bir faktördür. Günümüzde Çorum ili, tarihte ilk organize devlet olan Hititler'in başkenti Hattuşaş ve yine Hititler'in önemli kültür ve sanat merkezi olan Alacahöyük ören yerine ev sahipli yapmaktadır. Bu yönüyle Çorum köklü bir tarihe sahip; kültürel, tarihi, doğal ve gastronomi açısından zengin; ulaşıma elverişli doğal bir geçit üzerinde, Türkiye'nin başkenti Ankara ile yine ülkenin Karadeniz' de önemli bir liman şehri olan Samsun'u birbirine bağlayan karayolu üzerinde gelişmiş olan bir şehirdir. Ancak Çorum, Türkiye ve dünya turizm pazarından henüz kayda değer bir pay alamamıştır. Transit geçen veya günübirlikçi çoğunluğun oluşturduğu turistler mevcut olmakla beraber turizm hizmet arzının yetersiz olduğu görülmektedir Yine de bu denli önemli bir tarihe ev sahipliği yapan Çorum, gelir ve istihdam üreten önemli bir ekonomik gelişme aracı olarak kabul edilen turizm olgusu açısından umut verici olarak değerlendirilmelidir.

Bir bölgede turizm gelişimi faydası ve zararıyla en çok yerel halkın yaşamını etkilemektedir (Lee, 2013). Hangi destinasyonda olursa olsun yerel halkın turizme desteği sürdürülebilir bir destinasyon gelişimi ve işletmelerin hayatta kalabilmeleri için bir ön koşul olarak ele alınmaktadır (Gursoy, Chi ve Dyer, 2010). Literatür turistlerin belirli destinasyonlara yönelik sahip oldukları algılar ve destinasyon imajına ilişkin ölçümler sıklıkla yapılıyor olsa da yerel halkın yaşadığı destinasyonun turizm potansiyeline ilişkin algılarının ve bir turizm destinasyonu olarak yaşadıkları yere ilişkin zihinlerinde oluşan imajın ölçüldüğü çalışmaların sayısı oldukça azdır (Ramkissoon ve Nunkoo, 2011). Eğer bir destinasyonda turizm gelişiminin turistler yerine yerel halka fayda sağlaması hedefleniyorsa, yerel halkında da algılarının ölçülmesi ve zamana bağlı olarak destinasyon özelliklerinin nasıl geliştiğinin ve bu değişimlerin yerel halk tarafından nasıl algılandığının da düzenli olarak ölçülmesi gerekir (Stylidis vd., 2014). Bir destinasyona ilişkin o bölgede yaşayan yerel halkın potansiyelinin arttığını veya hâlihazırda yüksek bir turizm potansiyeline sahip olduğunu algılamaları, bölgenin kaynaklarının turizm bağlamında değerlendirilmesini ve bölgede turizmin gelişimini desteklemelerinde önemli bir unsur olarak karşımıza çıkmaktadır (Çakır ve Kodaş, 2020: 2).

$\mathrm{Bu}$ bakımdan yerel halkın turizm gelişimine yönelik tutumuna ilişkin literatürde Çorum bölgesine yönelik araştırmaların sayısının yeterli düzeyde olmaması nedeniyle Çorum yerel halkının turizm gelişimine yönelik tutumunun ne düzeyde olduğunun ölçülmesini amaçlayan bu çalışmanın literatüre katkı sağlayacağı düşünülmektedir. Ayrıca yatırımcılara, sektör temsilcilerine, yerel yönetimlere, yerel halka ve diğer ilgili paydaşlara önemli düzeyde katkı sunacağı öngörülmektedir.

\section{KAVRAMSAL ÇERÇEVE YEREL HALKIN TURIZM GELIŞIMINE YÖNELIKK TUTUMU}

Turizmin çok yönlü ve geniş bir kavram olması sebebiyle tek bir tanımı bulunmamaktadır. Turizm olayını tanımlama çalışmaları, literatürü uzun bir süre meşgul etmiştir. Tanımlama denemelerinde ilk başlarda turizmin ulaşım, ekonomi ve sosyoloji yönlerine ağırlık verilerek yapıldığı; sonrasında ise boş zaman ve dinlenme gibi unsurların da eklendiği görülmektedir (Dinçer vd., 2015: 1). Bu bakımdan en geniş kapsamlı tanımla, "Turizm; insanların sürekli 
konutlarının bulunduğu yer dışında devamlı olarak yerleşmemek, sadece para kazanmak veya politik ya da askeri bir amaç gütmemek üzere, serbest bir ortam içinde, iş, merak, din, sağlık, spor, dinlenme, eğlence, kültür, deneyim kazanma, snobik amaçlarla veya aile ziyareti, kongre ve seminerlere katılmak gibi nedenlerle, kişisel veya toplu olarak yaptıkları seyahatlerden, gittikleri yerlerde 24 saati aşan veya o yerin bir konaklama tesisinde en az bir geceleme ile konaklamalarından ortaya çıkan iş ve ilişkileri kapsayan, bir tüketim olayı, endüstri ve sosyal bir olaydır" (Demir ve Çevirgen, 2006: 18).

Kimi zaman savaş, durgunluk, salgınlar meydana gelse de uluslararası turizm endüstrisi aşamalı bir şekilde gelişmektedir. Gelişen teknoloji, ulaşım ve artan boş zaman ile daha önce keşfedilmemiş destinasyonlara gidilmektedir (Harrill, 2004: 264). Turizm, 21. yüzyılda ilerleme kaydeden en önemli hizmet sektörüdür. Turizm faaliyetlerine katılım ulusal ve uluslararası anlamda sürekli artış göstermektedir. Kıyı turizminde deniz, kum ve güneş üçlüsünün hâkim olduğu görülmektedir. Fakat insanların ilgi ve isteklerinde oluşan değişim turizm faaliyetlerinde yeni ve farklı arayışların artışına yansımıştır. Bu durum kıyı turizminden iç kesimlere doğru gelişen alternatif turizm çeşitlerinin ortaya çıkmasına sebep olmuştur. Sonucunda doğal, tarihi ve kültürel bakımdan önemli bir potansiyeli olan iç kesimlerde turizm alanları genişlemekte ve mekânsal değişiklikler görülmektedir (Özdemir ve Kervankıran, 2011: 2-3).

Tutum insan davranışını etkilediği bilinen bir olgudur. Ne var ki, tutum ile davranış arasında doğrudan bir ilişki her zaman kurulamamaktadır. Bilinen bir tutum, her kişide ve her ortamda aynı davranışı ortaya koymayabilir. Davranışların önceden kestirilmesi için tutumun ölçümü ve bazı kuralların saptanması gerekir. Ancak tutum analizi ile davranış saptanması arasındaki ilişkide üç temel ilke vardır (Sabuncuoğlu ve Vergiliel Tüz, 2016: 34);

- Genel tutumlar genel davranışların en önemli göstergeleridir,

- Çok özel konular karşısında belirli hale gelen özel tutumlar bu konular karşısındaki özel davranışların göstergesidir,

- Tutum ölçümünü takip eden kısa süreler içerisinde öngörülen tutum-davranış ilişkisi geçerliliğini korumaktadır.

Turizm gelişiminin yerel halk üzerindeki etkisinin, destinasyondaki bireyler arasında algılanma süreci söz konusudur. Bu algılama sürecinin başlaması için turizm gelişim aşamasında, destinasyondaki bireylerin turizm gelişiminin etkilerini algılaması gerekmektedir. Turizm gelişim etkilerinin algılanmasının ardından turizmin yerel halk üzerindeki etkileri günlük yaşamda kendini göstermeye başlar ve günlük yaşam içerisinde olumlu ya da olumsuz yönde sonuçlanır (Kim, 2002). Algılar tutumları etkilemektedir ve tutumlar algılanan nesne ile temasta bulunma sırasında geliştikleri için, tanımlayıcı veya düşünsel bir temele dayanmaktadır (İnceoğlu, 2010: 87). Bu noktada turizme ilişkin tutumlara yönelik de çeşitli görüşler bulunmaktadır. Butler (1980), turizmin yaşam döngüsü üzerinde gerçekleştirdiği araştırmada bir bölgede turizm faaliyetlerinin ilk gelişmeye başladığı süreçte, özellikle turizmin olumlu ekonomik etkilerinden dolayı, yerel halkın turizme karşı olumlu bir desteğinin bulunduğunu ancak ilerleyen süreçte sosyal, kültürel ve çevresel problemler hakkında endişelerin gelişmesiyle birlikte turizm desteğinin gerilemeye başlayacağını ifade etmektedir. Bu bilgiler paralelinde yerel halkın turizme bağlı tutum modellerine yer verilecektir.

\section{YEREL HALKIN TURIZME GELIŞİMINE YÖNELIKK TUTUMU İLE ÍLGILİ MODELLER}

Turizm potansiyeline sahip bölgelerde turizmin gelişmeye başlamasıyla yerel halkın davranışlarında meydana gelen değişimleri açıklayan çeşitli modeller ve teoriler bulunmaktadır. 
Doxey'in Rahatsızlık İndeksi Modeli: Doxey'in modelinde turizmin gelişimi ile ilgili bölgede yerel halkın turistlere yönelik davranışlarında gittikçe olumsuzluklar olacağı ileri sürülmektedir. Modelde dört aşama “Coşku (euphoria), ilgisizlik (apathy), rahatsızlık (annoyance) ve düşmanlık (antagonism)" yer almaktadır. Illk olarak yeni gelişen turizm bölgesine gelen turistler, sağladıkları gelir vb. bakımdan turizm olayına olumlu bakılmasını sağlamaktadır. Toplumun turistlere olumlu ve coşkulu şekilde davranış göstermesi; turistlerin destinasyondaki insanların kültürlerine olan ilgisi, ziyaretleri esnasında ihtiyaçlarını yerel halkın karşılaması ve yerel halka gelir sağlamaları ile açıklanmaktadır. Bu süreç Euphoria (keyif-coşku) olarak adlandırılmaktadır. Zaman içerisinde turizmin gelişerek devam etmesi ve turist sayısındaki artış olağan karşılanır. Ancak turistik işletmelerin çoğalması ve yabancı yatırımcıların kontrolünde olması, yerel halkın çoğunlukla hizmet eden pozisyonuna geçmesi, çeşitli eleştirilere sebep olabilmektedir. Bunun sonucunda ise ikinci aşama olan ilgisizlik (apathy) oluşur ve coşku yok olur. Bu aşamada turist ve yerel halk arasındaki ilişki daha resmi ve ticaridir. Üçüncü aşamada oluşan rahatsızlık (annoyance) ise taşıma kapasitesine erişildiğinde yani hali hazırdaki işletmelerin arzının talebi karşılayamaz duruma geldiğinde başlamaktadır. Dördüncü aşamada ise turizm bölgedeki başlıca ekonomik etkinlik iken doğal çevre ve sosyal düzende de meydana gelen kayıplar rahatsız edici düzeye ulaşmış olabilmektedir. Toplum artık turist ve turizm açısından doyum noktasında ulaşmıştır. Üçüncü aşamadaki rahatsızlık düşmanlığa dönüşmektedir. Düşmanlık (antagonism) adı verilen bu aşamada turistlere olumlu bakılmamakla beraber bir takım düşmanca davranışlarda sergilenebilmektedir. Turistler bütün olumsuzlukların sorumlusu olarak görülebilmektedir (Roney Akış, 2011: 110).

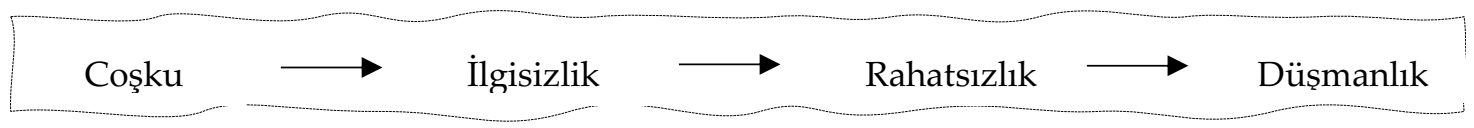

Şekil 1. Doxey Irridex Model

Kaynak: Ryan, 2003: 275.

Roney (2011) Doxey'in modeline yönelik yapılan en büyük eleştirel yaklaşım, yerel halkın homojen olarak aynı tepkileri verdiğinin düşünülmesi ve bu tepkilerin sadece tek yönlü oluştuğu düşüncesi ile irdelenmesidir.

Butler'ın Destinasyonların Yaşam Döngüsü Modeli: Bu modelde bir ürünün satışlarının ilk olarak yavaş ilerlediği, hızlı bir büyüme oranı yaşadığı, dengelendiği ve ardından düştüğü ürün döngüsü konseptine dayanmaktadır. Başka bir deyişle, temel bir asimptotik eğri izlenir. Ziyaretçiler, başlangıçta erişim, tesisler ve yerel bilgi eksikliği nedeniyle sinırlı olan az sayıda alana geleceklerdir. Tesisler sağlandıkça ve farkındalık arttıkça ziyaretçi sayısı artacaktır. Pazarlama, bilgi yayma ve daha fazla tesis sağlama ile bölgenin popülaritesi hızla artacaktır. Ancak nihayetinde, ziyaretçi sayısındaki artış oranı, taşıma kapasitesi seviyelerine ulaşıldıkça düşecektir. Bunlar çevresel faktörler (örn. arazi kıtllğı, su kalitesi, hava kalitesi), fiziksel tesis (örn. ulaşım, konaklama, diğer hizmetler) veya sosyal faktörler (örn. yerel nüfus tarafından ezilme, kızgınlık) açısından tanımlanabilir. Bölgenin çekiciliği diğer alanlara göre azaldığından, aşırı kullanım ve ziyaretçilerin etkileri nedeniyle, gerçek ziyaretçi sayısı da sonunda düşebilir (Butler, 1980: 6). Gerek Doxey'in Irridex Modeli gerekse Butler'ın destinasyon yaşam eğrisi, davranışların ne kadar önemli olduğuna vurgu yapmaktadır. Ayrıca toplulukların turizm gelişimi konusundaki değişkenliklerini sorgulamaktadır (Altıntaş, 2010: 10; Ersoy, 2017: 13). 
Doğan'ın Modeli-Turizmin Etkilerine Verilen Toplumsal Tepkiler: Bu model turizmin çeşitli etkileri sonucunda ortaya konulan toplumsal tepkiler olarak direnme, içine kapanma, sınırları vurgulama, canlandırma ve bütünleştirme olmak üzere beş grupta incelenmiştir (Doğan, 2004: 153-156):

Direnme: Bazı toplumlarda turizmin çeşitli etkileri benimsenememenin yanı sıra bu etkilere karşı etkin bir direniş ortaya çıktığını ifade etmektedir. Özellikle, sömürge durumundan yeni kurtulmuş, geçmişinde keskin bir ırk ayrımı olan topluluklarda, turizm yeni bir sömürgecilik şekli olarak düşünülmekte; turizme ve turistlere karşı olumsuz davranışlar oluşabilmektedir. Turizme direnme, bir bölgede, turizmden kaynaklanan başkalarına hizmet etme, emirlerine uyma zorunluluğunun sebep olduğu uşak psikolojisiyle bağlantılıdır.

İçine Kapanma: Turizmin bir toplumun yapısında meydana getirdiği değişmeler, toplumun çoğunluğunda ya da bazı kesimlerce benimsenmediğinde geleneksel kültürü bozucu bir etken olarak nitelendirilebilir. Bazen de turizme direnme ve düşmanlık yerine, toplumun içine kapanması, sahip olduğu gelenek ve yaşam şeklini canlandırması, kültürel bilincin artması yönünde bir tepki görülebilir.

Sınırları Vurgulama: Bir toplum, turizmin çeşitli etkilerine karşı çıkmak yerine, turizmi hem kabullenip hem de sahibi olduğu geleneksek kültür öğelerini olumsuz etkilerden koruyabilir. Bu yabancı kültürlerle yerli kültürler arasında sınırın çizilmesiyle, yerli kültürün turiste anlam değişikliği şeklinde sunularak kutsal ve gizemli özelliğini kaybetmesini önleyerek gerçekleştirebilir.

Canlandırma: Hem turizmin kabul edilmesi hem de geleneksek kültürün korunabilmesi, geleneksel kültürü turizmin bir parçası haline getirerek ve canlanmasını sağlayarak gerçekleştirilebilir. Kendi haline bırakılan birçok toplumda, sanayileşme, endüstrileşme ve kentleşmenin etkileri ile yavaş yavaş yok olan birçok gelenek, töre ve kurum turizmin etkisi altında yeniden anlam kazanmıştır. Kendi ülkemizden örnekler vermek gerekirse Mehter Takımının, folklor oyunlarının, geleneksel evlerin varlıkları turizm sayesinde canlanmış ve turistik işleviyle Türk kültürünün de canlılığını sağlamıştır.

Bütünleştirme: Bir toplumda, bazı kesimler turizmin oluşturduğu değişimleri benimseyebilir ve geleneksel kültürün etkisinin azalmasını normal karşılayabilir; ayrıca geleneksel kültürünün yok olması ve turizmin simgelediği çağdaş kültürün kabullenilmesi için çaba harcayabilir. Böyle bir durum genelde, yabancıların üstün bir kültürü yansıttığı ve yerli kültürün geri olarak algılandığ 1 toplumlarda görülmektedir.

$\mathrm{Bu}$ bilgiler ışı̆̆ında yukarıda incelenen tepkilerin çoğunlukla birlikte gerçekleşebileceği düşünülmelidir. Örneğin bir toplumda hem bütünleşme hem geleneksel kültürün bazı kesimlerinin canlanması, hem de kimi kesimlerde direnme, içine kapanma ve sınırları vurgulama birlikte görülebilir (Doğan, 2004: 156). Toplum temelli bir turizm hedefi için misafirlerin etkileşimde bulunduğu yerlerden yerel yaşam (barınma, hizmetler) ve doğal alanlarda bir ekosistem yaklaşımı benimsenerek ve değerlendirilerek bir turizm ürünü oluşturulabilir (Jamal ve Getz, 1995).

\section{TURIZZMIN ETKİLERI}

Turizm temelli aktiviteler, ürünler, hizmetler veya turistik alanların kalitesi ne olursa olsun turizm yerel topluluklara ve çevresine sosyal, ekonomik ve çevresel önemli etkiler bırakmaktadır. Ancak ortaya koyulan bu etkiler topluluktan topluluğa değişiklik göstermektedir. Turizm çeşitliliği arttıkça, sosyal-kültürel, ekonomik ve çevresel etkiler daha önemli hale gelmektedir (Dyer vd., 2007: 411). Turizm olgusunun karmaşık yapısı, turizm gelişiminin toplam etkisini 
ölçmeyi neredeyse imkânsız hale getirmektedir. Bu nedenle sosyal, ekonomik ve çevresel etkiler birbirine bağlıdır ve birbirinden etkilenmektedir (Nunkoo ve Ramkissoon, 2007: 140).

Turizmin Ekonomik Etkileri: Turizm en çok ekonomik yönüyle ele alınmış toplumsal bir etkinliktir. Gelir getirici ve döviz kazandırıcı özelliğinden dolayı ekonomik yaklaşımlı incelemeler yaygınlık kazanmıştır. Günümüzde ekonomik ve kitlesel bir olgu haline gelen turizmin ülke ekonomileri üzerinde olumlu etkileri, turizmin olumlu ekonomik yönünü daha da ön plana çıkarmıştır. Fakat turizmin ekonomik etkilerine iyimser açıdan bakan yaklaşım, söz konusu etkilerin olumsuz olabileceğini ortaya koyacak araştırma ve incelemelerin yapılmasını ve bunların sistematik bir şekilde çözüme kavuşturulmasını uzun süre engellemiştir. Hiç kuşkusuz turizmin ülke ekonomisi üzerinde olumlu ve olumsuz birtakım etkileri olacaktır. Bunlar tablo 1' de sunulmuştur (Kozak, Akoğlan Kozak ve Kozak, 2017).

Tablo 1. Turizmin Ekonomik Etkileri

\begin{tabular}{|l|l|}
\hline Olumlu Etkiler & Olumsuz Etkiler \\
\hline Ödemeler dengesi üzerindeki etkisi & Fırsat maliyeti \\
\hline Gelir yaratıcı etkisi & Dışalım eğilimindeki artış \\
\hline İstihdam yaratıcı etkisi & Yabancı işgücü gereksinmesi \\
\hline Bölgelerarası dengeli kalkınmaya etkisi & Mevsimlik dalgalanma \\
\hline Altyapı ve üstyapı yatırımlarına etkisi & Enflasyonist baskı \\
\hline Diğer ekonomik sektörlere katkı & Turizme aşırı bağımlılık \\
\hline
\end{tabular}

Kaynak: Kozak vd., 2017: 110-121.

Turizmin Sosyo-Kültürel Etkileri: Sosyal yapı bir toplumda örgütlenmiş ilişkilerin bütünü olarak değerlendirildiğinde; gelişmiş veya az gelişmiş ülkeleri, kırsal veya kentsel toplumları, farklı coğrafyadan insanları birleştiren turizm olgusunun sosyal yapıyı etkilemesi kaçınılmaz olmaktadır. Dolayısıyla bir toplumun ürettiği maddi (tarihi ve arkeolojik eserler, özgün mimari, el sanatları, giyim kuşam) ve manevi (gelenekler, dinsel törenler) değerlerin hepsi şeklinde değerlendirilen kültürün de değişmesi muhtemel olmaktadır. Kültür turistik çekiciliğin önemli bir unsurudur ve turizm için turist ve yerel halkın uyumlu olması olumlu sonuçları da beraberinde getirebilmektedir (Roney Akış, 2011: 1005).

Turizmin Çevresel Etkileri: Turizm ürünlerinin temel merkezi çevredir ve turistler bu çevrenin tüketicileridir. Farklı bir ifadeyle, turizm destinasyonları çevresel kaynaklara her daim ihtiyaç duymaktadır. Turizmin varlık göstermesi için turiste hitap eden bir çevre gerekmektedir. Tarihi ve kültürel yerler, iklim, doğa ve doğal manzara birer çevre unsurudur. Bazı bölge ve alanlar, doğal özelliklerin bir arada yoğunlaşması ve çeşitliliğin bol olması bakımından diğer bölge ve alanlardan daha avantajlı bir duruma gelmektedir. Doğal çevreye ilişkin bazı özellikler bölgeleri turizm açısından daha cazip hale getirmektedir. Bu sebeple çevre, bir bölgeye yönelik turizm hareketlerinin doğmasında ve gelişmesinde en önemli etkenlerden biridir (Dal, 2008: 70). 
Tablo 2. Turizmin Sosyo-Kültürel Etkileri

\begin{tabular}{|c|c|}
\hline Olumlu & Olumsuz \\
\hline \multicolumn{2}{|c|}{ Nüfus üzerine etkiler } \\
\hline \multicolumn{2}{|l|}{ Nüfus artışı (göç, göç yokken) } \\
\hline \multicolumn{2}{|c|}{$\begin{array}{c}\text { Mevsimlik işgücü göçü } \\
\text { (Çalışılmasıyla olumlu/İşsiz kalınmasıyla olumsuz) }\end{array}$} \\
\hline \multicolumn{2}{|c|}{$\begin{array}{c}\text { İkinci konut sahiplerinin varlığı } \\
\text { (Toplumsal hayatta yer almalarıla olumlu/Yer almamalarıyla olumsuz) }\end{array}$} \\
\hline \multicolumn{2}{|c|}{ Nüfus dağılımında değişiklikler (yaş, cinsiyet, ırk, etnik) } \\
\hline \multicolumn{2}{|c|}{ Nüfusun kentleşmesi } \\
\hline \multicolumn{2}{|c|}{ İşgücü pazarında değişiklikler } \\
\hline Yeni işler & Mevsimlik işçiler \\
\hline Turizmden yeni iş türleri & Deneyimsiz işçiler \\
\hline Bilginin değerinin artması, dil becerisi & Geleneksel alanlarda iş gücü eksikliği \\
\hline Ekonomik çeşitlenme & Ekonomik eşitsizlik artışı \\
\hline Az gelişmiş bölgelerin teşviki & \\
\hline \multicolumn{2}{|c|}{ Toplumsal yapı ve özelliklerinde değişiklikler } \\
\hline Turizmden gelir elde etme & $\begin{array}{l}\text { Geçici oturanların oranın artışı (fazla bağlılık } \\
\text { olmadan) }\end{array}$ \\
\hline Hizmet sektörünün öneminin artması & İkinci konut sahipleri ile çatışma \\
\hline Sosyal, kültürel hayatın teşviki & Gayrimenkul edinmede zorluklar \\
\hline Arsa değerlerinin artışı & Gayrimenkul fiyatlarının artışı \\
\hline Alt yapının gelişmesi & Fiyat artışı, enflasyon \\
\hline Daha fazla alışveriş fırsatı & Kültürel kimlik kaybı \\
\hline Destinasyon imajında düzelme & Değer sistemlerinin dönüşümü \\
\hline Yerli halkın gururlanma artışı & Dini çatışma (ikincil konut sahipleri turistlerle) \\
\hline $\begin{array}{l}\text { Önyargıların azalması, kalıplaşmanın bitmesi, } \\
\text { hoşgörü artışı }\end{array}$ & Turizme fazla bağlılık \\
\hline & Kalabalıklaşma, trafik sorunları \\
\hline \multicolumn{2}{|c|}{$\begin{array}{l}\text { Sosyal katmanlaşmanın değişimi (turistik kaynak sahiplerinin artması, geleneksel kaynak sahiplerinin } \\
\text { azalması) }\end{array}$} \\
\hline \multicolumn{2}{|c|}{ Birey ve aile üzerine etkiler } \\
\hline $\begin{array}{l}\text { Sosyal hareketlilik artışı (özellikle gençler ve } \\
\text { kadınlar arasında) }\end{array}$ & Sosyal ağların bozulması \\
\hline Eğlence imkânlarının gelişmesi & Yaşam düzeyinde değişiklik \\
\hline Yeni kişilerle tanışma, daha geniş sosyal ilişkiler & Arkadaşlığın önemini yitirmesi \\
\hline Yaşam kalitesinde artış & Tehlike algısında artış (artan suçlar) \\
\hline Dil becerileri & Yabancı düşmanlığı \\
\hline Turizmden gelir elde etme & Ticarileşen konukseverlik \\
\hline Nezaket, görgü, çalışan davranışlarında iyileşme & $\begin{array}{l}\text { Sapkin davranışlar (alkolizm, fuhuş, kumar, } \\
\text { uyuşturucu, vandalizm) }\end{array}$ \\
\hline & Yerel dilin bastırılması \\
\hline & Cinsel hareket serbestliğinde artış \\
\hline \multicolumn{2}{|c|}{ Aile yapısında değişiklik } \\
\hline \multicolumn{2}{|c|}{ Tüketici alışkanlıklarında değişiklik } \\
\hline \multicolumn{2}{|c|}{ Barınma koşullarında değişiklik } \\
\hline \multicolumn{2}{|c|}{ Davranış değişikliği (özendirmenin etkisi) } \\
\hline \multicolumn{2}{|c|}{ Kültürel ve doğal kaynaklar üzerinde etki } \\
\hline Seçkin güzellikteki ender yerlerin korunması & Yerel gelenek-göreneklerin yok olması \\
\hline Yerel sanat, el işi ve kültürel olayların canlanması & Kültürün ticarileşmesi \\
\hline Mimari geleneklerin canlanması & Çöp sorunu ve kirlenme \\
\hline
\end{tabular}

Kaynak: Ratz, 2000: 6-7. 
Turizm, fiziksel çevre üzerinde bozulmalara sebep olabilmekte ve kendi varlığını da tehlikeye sokabilmektedir. Fakat çevresel değerlere artı bir zenginlik sağladığında ise kendisinin devamlılığını sürdürme noktasında önemli bir katkı sağlamış olmaktadır. Bu çerçevede, turizmin doğal çevre üzerinde bozulmalara sebep olabilecek olumsuz etkilerinin azaltılması ve çevresel zenginliğe katkı sağlayacak olumlu etkilerinin artırılması gerekmektedir (Kahraman ve Türkay, 2012: 60). Turizmin, planlı ve kontrollü olarak gelişmesine bağlı olarak olumlu ve olumsuz çevresel etkileri söz konusudur (Lickorish ve Jenkins, 1997: 87-89). Bular Tablo 3'te özetlenmiştir.

Tablo 3. Turizmin Çevresel Etkileri

\begin{tabular}{|l|l|}
\hline Olumlu Etkiler & Olumsuz Etkiler \\
\hline Önemli doğal alanların korunması & Su kirliliği \\
\hline Arkeolojik ve tarihi alanların korunması & Hava kirliliği \\
\hline Çevre kalitesinin yükseltilmesi & Gürültü kirliliği \\
\hline Çevre değerinin artırılması & Görsel kirlilik \\
\hline Altyapı ve üstyapının geliştirilmesi & Kalabalık ve izdiham \\
\hline & Arazi kullanım sorunları \\
\hline & Ekolojik bozulma \\
\hline & Çevresel tehlikeler \\
\hline & Tarihi ve arkeolojik alanlara verilen zarar \\
\hline & Uygunsuz atık yok etme \\
\hline
\end{tabular}

Kaynak: Lickorish ve Jenkins, 1997: 87-89.

Genel olarak değerlendirildiğinde turizm olgusu bir bölgenin gelişimi açısından önemli bir faaliyet olarak değerlendirilmektedir. Bunun yanında turizm faaliyeti bütüncül olarak ekonomik, sosyal ve çevresel faktörler üzerinde oldukça etkili olmaktadır. Bu durum ise bölgesel kalkınmayı doğrudan etkileyebilmektedir. Ancak bu etki her zaman olumlu bir şekilde gelişmemekte olup, bazen olumlu bazen de olumsuz etkiler ortaya çıarabilmektedir. Turizm kaynaklı bu olumsuz etkilerin ortadan kaldırılması veya olumluya çevrilmesi ise turizm faaliyetlerinin devamlılı̆̆ı ve daha da gelişmesi bakımından kritik öneme sahiptir.

\section{YÖNTEM}

Araştırmanın temel amacı Çorum ili yerel halkının henüz emekleme aşamasında olan ve birçok alternatif türlere sahip, turizm olgusuna ve faaliyetlerine yönelik tutumunun ortaya koyulmasıdır. Araştırmada yerel halkın turizm gelişimine yönelik olarak tutum düzeylerinin demografik özelliklerine göre farklılaştığı varsayılmaktadır. Bu bağlamda araştırmada, yerel halkın turizm gelişimine yönelik olarak tutumu incelenmiş ve araştırma hipotezleri şu şekilde geliştirilmiştir:

H1: Yerel halkın turizm gelişimine yönelik tutum düzeylerine ilişkin görüşleri cinsiyet özelliğine göre anlamlı bir farklılık gösterir.

H2: Yerel halkın turizm gelişimine yönelik tutum düzeylerine ilişkin görüşleri yaş özelliğine göre anlamlı bir farklılık gösterir.

H3: Yerel halkın turizm gelişimine yönelik tutum düzeylerine ilişkin görüşleri eğitim durumu özelliğine göre anlamlı bir farklılık gösterir. 
H4: Yerel halkın turizm gelişimine yönelik tutum düzeylerine ilişkin görüşleri meslek özelliğine göre anlamlı bir farklılık gösterir.

H5: Yerel halkın turizm gelişimine yönelik tutum düzeylerine ilişkin görüşleri aylık gelir özelliğine göre anlamlı bir farklılık gösterir.

Araştırma kapsamında oluşturulan hipotezlerin test edilmesi için örneklem belirlenmiş ve anket tekniği kullanılarak veriler elde edilmiştir. Uygulamalı bir nitelik taşıyan bu araştırmanın evrenini Çorum'da yaşayan yerel halk oluşturmakta olup, belirlenen evren üzerinden kolayda örneklem yöntemi ile örneklem alma yoluna gidilmiştir. Evreni oluşturan yerel halkın sayısı 10.000'den fazla olduğundan, Özdamar (2001: 257) tarafından sınırsız evrenler $(N>10.000)$ ve nicel araştırmalar için önerilen $\left(n=\sigma^{2} Z^{2} / H^{2}\right)$ formülden yararlanılmıştır. Formüldeki standart sapma değeri 80 kişilik pilot uygulama sonucunda $(\sigma) 1$ olarak belirlenmiş, 0,05 anlamlılık düzeyine karşılık $Z \alpha$ teorik değeri 1,96 ve hata değeri, (H) 0,1 alınmıştır. Parametreler formülde yerine konulduğunda minimum örneklem hacmi 384 olarak hesaplanmıştır. Anketlerin uygulanabilmesi için 14.06.2021 tarih ve 7 sayılı Etik Kurul İzni Nevşehir Hacı Bektaş Veli Üniversitesinden alınmıştır. Etik Kurul İzni alındıktan sonra Haziran 2021 içerisindeki sürede Çorum ilindeki gönüllü olan kişilerden anket tekniği ile veriler elde edilmiştir. Bu doğrultuda cevaplanması istenen anketlerde eksik, hatalı ve geriye dönmeyecek anketlerin de olabileceği göz önünde bulundurularak 500 anket dağıtılmış ve sonuçta geçerli 424 anket değerlendirmeye alınmıştır.

Araştırmada kullanılan anketin birinci bölümünde katılımcıların demografik özelliklerini belirlemek üzere oluşturulmuş olan sorulara (cinsiyet, medeni durum, yaş, eğitim durumu, mesleğiniz, aylık geliriniz ve Çorum'da ikamet süreniz) yer verilmiştir. Anketin ikinci bölümünde yerel halkın turizm gelişimine yönelik tutumunu belirlemek amacıyla Değerliyurt vd., (2013)'nin geliştirdiği on sekiz maddeden oluşan ölçeğe yer verilmiştir. Ölçek ekonomik, sosyal ve çevresel olmak üzere üç boyuttan oluşmakta ve beşli Likerttir. Araştırmada kullanılan ölçeğe ilişkin Değerliyurt vd., (2013) geçerlik ve güvenirlik çalışmasını yapmış ve güvenirlik katsayısını "Cronbach Alpha" 0,72 olarak tespit etmişlerdir. Araştırmada kullanılan yerel halkın turizm gelişimine yönelik tutumu ölçeğinde geçerlik ve güvenirlik çalışması yapılmıştır. Güvenirlik analizi kapsamında araştırma değişkenlerinin içsel tutarlılıklarının ortaya konulabilmesi amacıyla Cronbah Alpha değerleri hesaplanmış ve Cronbach Alpha 0,89 olarak hesaplanmıştır. Ölçeklerin geçerliliklerini test etmek için yakınsak ve uzaksak geçerlilik analizinden yararlanılmıştır. Yerel halkın turizm gelişimine yönelik tutum ölçeğinde yer alan her bir ifadenin kendi boyutu ve diğer boyutlarla olan korelasyonu incelenmiştir. Analiz neticesinde yerel halkın turizm gelişimine yönelik tutum ölçeğinde yer alan her bir ifadenin kendi boyutu ile gösterdiği korelasyonun diğer boyutlarla gösterdiği korelasyondan yüksek olduğu görülmüştür. Ölçeğin yakınsak geçerliliği için ise bütün alt boyutların birbiriyle olan korelasyonu incelenmiştir. Bu analizde, alt ölçeklerin birbiriyle olan korelasyonunun düşük fakat aynı zamanda olumlu olması gerekmektedir (Altunışık vd., 2012; Judd vd., 1991: 165). Yakınsak geçerlilik analizi sonuçları incelendiğinde her bir alt ölçeğin diğeriyle olan korelasyonu düşük fakat $p<0,01$ ve $p<0,05$ düzeyinde olumlu ve anlamlı olduğu görülmektedir.

Elde edilen veriler bilgisayar ortamına aktarılmıs, eksik ve hatalı kodlama olasıllı̆ı göz önünde tutularak tüm verilerin frekans dağılımları irdelenmiştir. Araştırma amacı doğrultusunda verilerin istatistiksel analizlerine geçmeden önce tüm parametrik testler için ön koşul olarak, toplanan verilerin normal dağılım gösterip göstermediği test edilmiştir. Toplanan verilerin normal dağılıma sahip olup olmadığını test etmek amacıyla ise çarpıklık ve basıklık değerleri hesaplanmıştır. Literatürde çarpıklık (skewness) ve basıklık (kurtosis) değerlerinin $+1,5$ ile $-1,5$ değerleri arasında olduğu durumlarda dağılımın normal dağılım olarak gerçekleştiği kabul edilmektedir. Bazı kaynaklara göre ise $\pm 2, \pm 3$ arası değerler almaktadır (George ve Mallery, 2010; 
Altunışık vd., 2012). Bu kapsamda yerel halkın turizm gelişimine yönelik tutumu ölçeğine yönelik ölçek ifadelerinin çarpıklık $(-0,211)$ ve basıklık $(0,187)$ değerleri \pm 2 değerleri arasında olduğundan çalışma verilerinin dağılımının normal dağılım gösterdiğini söylemek mümkündür. Yapılan analizler neticesinde verilerin normal dağılım göstermesi ve örneklem büyüklügünün yeterli olmasından dolayı verilerin parametrik testler için uygun olduğu da söylenebilir. Bu doğrultuda çalışmada yerel halkın turizm gelişimine yönelik tutumuna ilişkin demografik özellikleri temelinde farklılıkları belirlemek için bağımsız örneklem t-testi ve varyans analizinden yararlanılmıştır. Yapılan analizler sonucunda elde edilen veriler bulgular kısmında tablo olarak verilmiş ve yorumlanmıştır.

\section{BULGULAR}

Bu kısımda araştırma sonucunda elde edilen bulgulara ilişkin analiz sonuçlarına yer verilmiştir. Araştırma kapsamında elde edilen veriler, tanımlayıcı analizler (frekans, yüzde, ortalama, standart sapma), t-testi ve Anova ile analiz edilmiştir. Araştırmaya katılanların demografik özelliklerine ilişkin bulgular Tablo 4 'te yer almaktadır.

Tablo 4. Katılımcıların Demografik Özelliklerine Göre Frekans ve Yüzde Dağılımları

\begin{tabular}{|c|c|c|c|}
\hline Değişkenler & Gruplar & $\mathrm{f}$ & $\%$ \\
\hline \multirow{2}{*}{ Cinsiyet } & Erkek & 218 & 51,4 \\
\hline & Kadın & 206 & 48,6 \\
\hline \multirow{2}{*}{ Medeni Durum } & Evli & 102 & 24,1 \\
\hline & Bekâr & 322 & 75,9 \\
\hline \multirow{5}{*}{ Yaş } & 25 ve alt 1 & 286 & 67,5 \\
\hline & $26-35$ & 78 & 18,4 \\
\hline & $36-45$ & 44 & 10,4 \\
\hline & $46-55$ & 16 & 3,8 \\
\hline & 56 ve üzeri & 0 & 0 \\
\hline \multirow{5}{*}{ Eğitim Durumu } & İlköğretim & 36 & 8,5 \\
\hline & Lise & 192 & 45,3 \\
\hline & Önlisans & 50 & 11,8 \\
\hline & Lisans & 134 & 31,6 \\
\hline & Lisansüstü & 12 & 2,8 \\
\hline \multirow{8}{*}{ Meslek } & Öğrenci & 190 & 44,8 \\
\hline & Ev hanımı & 24 & 5,7 \\
\hline & $\underline{\text { Esnaf }}$ & 48 & 11,3 \\
\hline & Devlet Memuru & 36 & 8,5 \\
\hline & Çiftçi & 12 & 2,8 \\
\hline & İşçi & 40 & 9,4 \\
\hline & İssiz & 38 & 9,0 \\
\hline & Diğer & 36 & 8,5 \\
\hline \multirow{7}{*}{ Gelir Durumu } & $1000 \mathrm{TL}$ ve alt & 210 & 49,5 \\
\hline & $1001-2000 \mathrm{TL}$ & 40 & 9,4 \\
\hline & $2001-3000 \mathrm{TL}$ & 62 & 14,6 \\
\hline & $3001-4000 \mathrm{TL}$ & 30 & 7,1 \\
\hline & $4001-5000 \mathrm{TL}$ & 50 & 11,8 \\
\hline & 5001 ve daha çok & 0 & 0 \\
\hline & Gelirim yok & 32 & 7,5 \\
\hline \multirow{5}{*}{ İkamet Süresi } & 1 yıldan az & 30 & 7,1 \\
\hline & $1-5$ yil & 38 & 9,0 \\
\hline & 6-10 yil & 20 & 4,7 \\
\hline & $11-15$ y1l & 46 & 10,8 \\
\hline & 16 yıl ve üzeri & 290 & 68,4 \\
\hline
\end{tabular}


Tablo 4'te ki dağılıma göre araştırma kapsamındaki 424 yerel halkın \%51,4'ü erkek olup, \%48,6'sı ise kadındır. Medeni durumlarına yönelik olarak \%24,1'i evli, \%75,9'u bekârdır. Yerel halkın yaşlarına göre dağılımı incelendiğinde, $\% 67,5^{\prime}$ inin 25 ve altı yaş aralığında, \%18,4'ü 26-35 yaş aralığında, \%10,4'ünün 36-45 yaş aralığında ve \%3,8'inin 46-55 yaş aralığında olduğu tespit edilmiştir. Araştırmaya dâhil edilen yerel halkın eğitim durumuna bakıldığında, \%8,5'inin ilköğretim, \%45,3'ünün lise, \%11,8'i önlisans, \%31,6's1 lisans ve \%2,8'i lisansüstü eğitim derecesine sahiptir. Meslekleri itibariyle $\% 44,8^{\prime}$ i öğrenci, $\% 5,7^{\prime}$ si ev hanımı, $\% 11,3$ 'ü esnaf, $\% 8,5^{\prime}$ i devlet memuru, \%2,8 çiftçi, \%9,4'ü işçi, \%9'u işsiz ve \%8,5'inin diğer meslek gruplarından birine sahip olduğu görülmektedir. Yerel halkın aylık gelirleri incelendiğinde gelirim yok diyen kişiler \%7,5'i oluşturmakta olup, katılımciların \%49,5'i 1000 TL ve altı, \%9,4'ü 1001-2000 TL arası, $\% 14,6^{\prime}$ s1 2001-3000 TL aras1, \%7,1'i 3001-4000 TL arası ve \%11,8'i ise 4001-5000 TL aylık gelir elde ettiklerini belirtmiştir. Son olarak ilgili tabloda bulunan ve örneklem grubunda yer alan yerel halkın ildeki ikamet süresine göre dağılımı incelendiğinde, katılımcıların \%7,1'i bölgedeki ikamet süresinin 1 yılın altında, \%9'unun 1-5 yıl arasında, \%4,7'sinin 6-10 yıl arasında, \%10,8'inin 11-15 yıl arasında ve \%68,4ünün ise 16 yıl ve üzerinde olduğu görülmektedir.

Tablo 5. Ekonomik Alt Boyuta İlişkin Betimsel İstatistikler ( $\mathrm{n}=424)$

\begin{tabular}{|c|c|c|c|c|c|c|c|c|}
\hline \multirow{2}{*}{ Ífadeler } & & \multicolumn{5}{|c|}{ S1klık Düzeyi } & \multirow[b]{2}{*}{$\bar{X}$} & \multirow[b]{2}{*}{ s.s. } \\
\hline & & (1) & (2) & (3) & (4) & (5) & & \\
\hline \multirow{2}{*}{$\begin{array}{l}\text { 1. Turizm, Çorum'a (yerel halka) ek gelir ve } \\
\text { kazanç sağlar. }\end{array}$} & $\mathrm{f}$ & 76 & 72 & 96 & 52 & 128 & \multirow{2}{*}{3,19} & \multirow{2}{*}{1,47} \\
\hline & $\%$ & 17,9 & 17,0 & 22,6 & 12,3 & 30,2 & & \\
\hline \multirow{2}{*}{ 2. Turizm, yalnızca yatırımcılarına kazanç sağlar. } & $\mathrm{f}$ & 104 & 110 & 98 & 46 & 66 & \multirow{2}{*}{2,66} & \multirow{2}{*}{1,36} \\
\hline & $\%$ & 24,5 & 25,9 & 23,1 & 10,8 & 15,6 & & \\
\hline \multirow{2}{*}{$\begin{array}{l}\text { 3. Turizm, ilde yeni iş alanlarının } \\
\text { oluşturulmasında etkili rol oynar. }\end{array}$} & $\mathrm{f}$ & 32 & 54 & 94 & 60 & 184 & \multirow{2}{*}{3,73} & \multirow{2}{*}{1,33} \\
\hline & $\%$ & 7,5 & 12,7 & 22,2 & 14,2 & 43,4 & & \\
\hline \multirow{2}{*}{$\begin{array}{l}\text { 4. Turizm, ildeki hayat şartlarının iyileşmesini } \\
\text { sağlar. }\end{array}$} & $\mathrm{f}$ & 28 & 60 & 74 & 78 & 184 & \multirow{2}{*}{3,77} & \multirow{2}{*}{1,31} \\
\hline & $\%$ & 6,6 & 14,2 & 17,5 & 18,4 & 43,4 & & \\
\hline \multirow{2}{*}{ 5. Turizm, ilde hayat pahalılığına neden olur. } & $\mathrm{f}$ & 62 & 44 & 140 & 80 & 98 & \multirow{2}{*}{3,25} & \multirow{2}{*}{1,31} \\
\hline & $\%$ & 14,6 & 10,4 & 33,0 & 18,9 & 23,1 & & \\
\hline \multirow{2}{*}{$\begin{array}{l}\text { 6. Turizm, ilde arsa ve ev fiyatlarının artmasina } \\
\text { neden olur. }\end{array}$} & $\mathrm{f}$ & 28 & 50 & 94 & 94 & 158 & \multirow{2}{*}{3,71} & \multirow{2}{*}{1,25} \\
\hline & $\%$ & 6,6 & 11,8 & 22,2 & 22,2 & 37,3 & & \\
\hline \multirow{2}{*}{$\begin{array}{l}\text { 7. Turizm, ilde konaklama, ulaştırma ve benzeri } \\
\text { hizmet sektörünün gelişmesini sağlar. }\end{array}$} & $\mathrm{f}$ & 18 & 28 & 72 & 80 & 228 & \multirow{2}{*}{4,12} & \multirow{2}{*}{1,13} \\
\hline & $\%$ & 3,8 & 6,6 & 17,0 & 18,9 & 53,8 & & \\
\hline \multirow{2}{*}{$\begin{array}{l}\text { 8. Turizm, ilde altyapı ve üstyapının } \\
\text { iyileştirilmesinde etkin rol oynar. }\end{array}$} & $\mathrm{f}$ & 8 & 32 & 102 & 78 & 204 & \multirow{2}{*}{4,03} & \multirow{2}{*}{1,09} \\
\hline & $\%$ & 1,9 & 7,5 & 24,1 & 18,4 & 48,1 & & \\
\hline$G$ & & & & & & & 3,56 & 0,84 \\
\hline
\end{tabular}

Ölçek 1: 1=Hiç katılmıyorum, 2= Az katılıyorum, 3= Orta düzeyde katılıyorum, 4= Çok katılıyorum, 5= Tamamen katılıyorum.

Tablo 5 'te yerel halkın turizm gelişimine yönelik tutumuna ilişkin ekonomik alt boyutta yer alan her bir ifadenin aritmetik ortalama değerleri değerlendirildiğinde, bu boyuta ait genel ortalama değeri "çok katılıyorum" seçeneğine karşılık gelmektedir $(\overline{\mathrm{X}}=3,56)$. Bu değer ekonomik alt boyuta ilişkin yüksek düzeyde bir tutum olduğunu göstermektedir.

Ekonomik açıdan turizmin sonuçlarına yönelik yerel halkın tutumuna bakıldığında, en yüksek ortalamanın "Turizm, ilde konaklama, ulaştırma ve benzeri hizmet sektörünün gelişmesini 
sağlar" $(\overline{\mathrm{X}}=4,12)$ ifadesinde hesaplandığ görülmektedir. Bu ifadeye katılımcıların \%10,4'ü "Hiç Katılmıyorum" ve "Az Katılıyorum" seçenekleriyle düşük düzeyde katılım gösterirken, \%89,7'si "Orta Düzeyde Katılıyorum", "Çok Katılıyorum" ve "Tamamen Katılıyorum" seçenekleriyle yüksek düzeyde görüş bildirmişlerdir. Bu bağlamda yerel halkın yüksek düzeydeki bu tutumlarını turizmin en temel sonucu olan konaklama, ulaşım vd. hizmet sektörü gelişmesine olan genel bilgilerinden kaynaklı olduğu söylenebilir. En düşük ortalamanın ise "Turizm, yalnızca yatırımcılarına kazanç sağlar" ( $\overline{\mathrm{X}}=2,66)$, ifadesinde saptanmıştır. Bu durum yerel halkın yükselen bir turizm gelişimi olması durumunda sadece yatırımcı değil ilgili tüm paydaşlara kazanç sağlayacağı düşüncesi ile açılanabilir.

Tablo 6. Sosyal Alt Boyuta İlişkin Betimsel İstatistikler (n424)

\begin{tabular}{|c|c|c|c|c|c|c|c|}
\hline \multirow{2}{*}{ İfadeler } & \multicolumn{5}{|c|}{ Sıklık Düzeyi } & \multirow[b]{2}{*}{$\bar{X}$} & \multirow[b]{2}{*}{ s.s. } \\
\hline & (1) & (2) & (3) & (4) & (5) & & \\
\hline \multirow{2}{*}{$\begin{array}{l}\text { 9. Turizm, il genelinde sosyal diyalog ve } \\
\text { entegrasyonun artmasını sağlar. }\end{array}$} & 22 & 26 & 84 & 118 & 174 & \multirow{2}{*}{3,93} & \multirow{2}{*}{1,14} \\
\hline & 5,2 & 6,1 & 19,8 & 27,8 & 41,0 & & \\
\hline \multirow{2}{*}{$\begin{array}{l}\text { 10. Turizm, yerel halkın ahlaki kurallarına aykırı } \\
\text { düşer. }\end{array}$} & 244 & 64 & 42 & 26 & 48 & \multirow{2}{*}{1,98} & \multirow{2}{*}{1,39} \\
\hline & 57,5 & 15,1 & 9,9 & 6,1 & 11,3 & & \\
\hline \multirow{2}{*}{ 11. Turizm, ilde ahlaki yozlaşmaya neden olur. } & 266 & 58 & 32 & 12 & 56 & \multirow{2}{*}{1,90} & \multirow{2}{*}{1,41} \\
\hline & 62,7 & 13,7 & 7,5 & 2,8 & 13,2 & & \\
\hline \multirow{2}{*}{$\begin{array}{l}\text { 12. Turizm, kültürümüzü ve insanımızı tanıtmak için } \\
\text { iyi bir fırsattır. }\end{array}$} & 14 & 16 & 42 & 82 & 270 & \multirow{2}{*}{4,36} & \multirow{2}{*}{1,02} \\
\hline & 3,3 & 3,8 & 9,9 & 19,3 & 63,7 & & \\
\hline \multirow{2}{*}{$\begin{array}{l}\text { 13. Turizm, ülkede Çorum algısının iyileştirilmesine } \\
\text { katkı sağlar. }\end{array}$} & 10 & 24 & 46 & 92 & 252 & \multirow{2}{*}{4,30} & \multirow{2}{*}{1,02} \\
\hline & 2,4 & 5,7 & 10,8 & 21,7 & 59,4 & & \\
\hline \multirow{2}{*}{ 14. Turizm, Çorum’a geri göçü sağlar. } & 84 & 38 & 104 & 36 & 162 & \multirow{2}{*}{3,36} & \multirow{2}{*}{1,53} \\
\hline & 19,8 & 9,0 & 24,5 & 8,5 & 38,2 & & \\
\hline
\end{tabular}

Ölçek 1: 1=Hiç katılmıyorum, 2= Az katıllıorum, 3= Orta düzeyde katılıyorum, $4=$ Çok katıliyorum, $5=$ Tamamen katılıyorum

Tablo 6' da yerel halkın turizm gelişimine yönelik tutumuna ilişkin sosyal alt boyutta yer alan her bir ifadenin aritmetik ortalama değerleri değerlendirildiğinde, bu boyuta ait genel ortalama değeri "orta düzde katılıyorum" seçeneğine karşılık gelmektedir $(\overline{\mathrm{X}}=3,30)$. Bu değer sosyal alt boyuta ilişkin orta düzeyde bir tutum olduğunu göstermektedir.

Sosyal açıdan turizmin sonuçlarına yönelik yerel halkın tutumuna bakıldığında, en yüksek ortalamanın "Turizm, kültürümüzü ve insanımızı tanıtmak için iyi bir fırsattır" $(\bar{X}=4,36)$ ifadesinde hesaplandığı görülmektedir. Bu ifadeye katılımcıların \%7,1'i “Hiç Katılmıyorum" ve "Az Katılıyorum" seçenekleriyle düşük düzeyde katılım gösterirken, \%92,9'u “Orta Düzeyde Katılıyorum", "Çok Katılıyorum" ve "Tamamen Katılıyorum" seçenekleriyle yüksek düzeyde görüş bildirmişlerdir. Bu bağlamda yerel halkın yüksek düzeydeki bu tutumlarının genel olarak sıcakkanlı, sosyal ve hoşgörülü olmasından kaynaklı olduğu söylenebilir. En düşük ortalama ise "Turizm, ilde ahlaki yozlaşmaya neden olur" $(\overline{\mathrm{X}}=1,90)$ ve "Turizm, yerel halkın ahlaki kurallarına aykırı düşer" ( $\overline{\mathrm{X}}=1,98)$, ifadesinde saptanmıştır. Bu durum araştırma esnasında ifadelere ilişkin yapılan yorumların ortalamasında yerel halkın öz bilincinin ve öz yeterliliğinin yüksek olduğuna dair oluşan düşünce ve araştırmaya katılanların genç ve eğitim düzeyi yüksek bireylerden oluşmasıyla açıklanabilir. 
Tablo 7. Çevresel Alt Boyuta İlişkin Betimsel İstatistikler ( $\mathrm{n}=424)$

\begin{tabular}{|c|c|c|c|c|c|c|c|}
\hline \multirow{2}{*}{ İfadeler } & \multicolumn{5}{|c|}{ Sıklık Düzeyi } & \multirow[b]{2}{*}{$\bar{X}$} & \multirow[b]{2}{*}{ s.s. } \\
\hline & (1) & (2) & (3) & (4) & (5) & & \\
\hline \multirow{2}{*}{$\begin{array}{l}\text { 15. Turizm, doğal kaynakların daha fazla } \\
\text { tüketilmesine neden olur. }\end{array}$} & 68 & 128 & 94 & 42 & 92 & \multirow{2}{*}{2,91} & \multirow{2}{*}{1,38} \\
\hline & 16,0 & 30,2 & 22,2 & 9,9 & 21,7 & & \\
\hline \multirow{2}{*}{ 16. Turizm, çevre kirliliği yaratır. } & 136 & 114 & 86 & 32 & 56 & \multirow{2}{*}{2,42} & \multirow{2}{*}{1,35} \\
\hline & 32,1 & 26,9 & 20,3 & 7,5 & 13,2 & & \\
\hline \multirow{2}{*}{$\begin{array}{l}\text { 17. Turizm, ildeki tarihi yapıların korunmasını } \\
\text { sağlar. }\end{array}$} & 20 & 22 & 48 & 96 & 238 & \multirow{2}{*}{4,20} & \multirow{2}{*}{1,12} \\
\hline & 4,7 & 5,2 & 11,3 & 22,6 & 56,1 & & \\
\hline \multirow{2}{*}{$\begin{array}{l}\text { 18. Turizm, ildeki yerel mimari ve mutfak } \\
\text { kültürünün korunmasını sağlar. }\end{array}$} & 10 & 26 & 66 & 90 & 232 & \multirow{2}{*}{4,19} & \multirow{2}{*}{1,06} \\
\hline & 2,4 & 6,1 & 15,6 & 21,2 & 54,7 & & \\
\hline GENEL & & & & & & 3,43 & 0,82 \\
\hline
\end{tabular}

Ölçek 1: 1=Hiç katılmıyorum, 2= Az katılıyorum, 3= Orta düzeyde katılıyorum, 4= Çok katıliyorum, $5=$ Tamamen katılıyorum

Tablo 7'de yerel halkın turizm gelişimine yönelik tutumuna ilişkin çevresel alt boyutta yer alan her bir ifadenin aritmetik ortalama değerleri değerlendirildiğinde, bu boyuta ait genel ortalama değeri "yüksek düzeyde katılıyorum" seçeneğine karşılık gelmektedir $(\bar{X}=3,43)$. Bu değer çevresel alt boyuta ilişkin orta düzeyde bir tutum olduğunu göstermektedir.

Çevresel açıdan turizmin sonuçlarına yönelik yerel halkın tutumuna bakıldığında, en yüksek ortalamanın "Turizm, ildeki tarihi yapıların korunmasını sağlar" $(\bar{X}=4,20)$ ifadesinde hesaplandığı görülmektedir. Bu ifadeye katılımcıların \%9,9'u "Hiç Katılmıyorum" ve "Az Katılıyorum" seçenekleriyle düşük düzeyde tutum gösterirken, \%90,1'i “Orta Düzeyde Katılıyorum", "Çok Katılıyorum" ve "Tamamen Katılıyorum” seçenekleriyle yüksek düzeyde görüş bildirmişlerdir. Bu durum bölgenin turizme entegre olmasıyla turizmin oluşturacağ katkılar da dikkate alındığında ve önemli bir nokta olan bölgenin kültür turizmine hizmet edecek olmasından dolayı bölgenin tarihi yapılarının daha da fazla korunmasını sağlanacağı düşüncesi ile açıklanabilir. En düşük ortalamanın ise "Turizm, çevre kirliliği yaratır" $(\bar{X}=2,42)$ ifadesinde saptanmıştır. Bu durum yine araştırma esnasında katılımcıların ifadelere ilişkin yapılan yorumlarında, turizmin olumsuz bu sonucuna ilişkin yerel yönetimler ve ilgili paydaşların alacağı önlemlerin etkili olacağı düşüncesi ile açıklanabilir.

Araştırma kapsamında yerel halkın turizm gelişimine yönelik tutumunun bireysel özellikler bağlamında ayrılan gruplar arasında fark olup olmadığını ortaya koymak amacıyla; bağımsız örneklemler için T-testi ve Anova testi uygulanmıştır. Ayrıca meydana gelen farklılığın hangi gruplardan kaynaklandığını belirlenmeye yönelik olarak, "Çoklu Karşılaştırma (tukey)" testinden yararlanılmıştır. Bu bağlamda anlamlı farklılığın oluşmadığı medeni durum ve ikamet süresi özelliği haricinde cinsiyet, yaş, eğitim durumu, meslek ve aylık gelir özelliklerine göre ayrılan gruplara ilişkin farklılık analizi sonuçlarına yer verilmiştir. 
Tablo 8. Yerel Halkın Turizm Gelişimine Yönelik Tutumunun Cinsiyet Özelliklerine Göre Karşılaştırılması (t-testi)

\begin{tabular}{|c|c|c|c|c|c|}
\hline Temel Değişken & Cinsiyet & $\bar{X}$ & s.s. & $\mathbf{t}$ & p \\
\hline \multirow{2}{*}{ Ekonomik } & Erkek & 3,66 & 0,90 & \multirow{2}{*}{2,569} & \multirow{2}{*}{$0,011^{*}$} \\
\hline & Kadın & 3,45 & 0,76 & & \\
\hline \multirow{2}{*}{ Sosyal } & Erkek & 3,44 & 0,85 & \multirow{2}{*}{3,627} & \multirow{2}{*}{$0,000^{*}$} \\
\hline & Kadın & 3,16 & 0,75 & & \\
\hline \multirow{2}{*}{ Çevresel } & Erkek & 3,50 & 0,79 & \multirow{2}{*}{1,908} & \multirow{2}{*}{0,057} \\
\hline & Kadın & 3,35 & 0,84 & & \\
\hline \multirow{2}{*}{ Genel Turizm Gelişimine Yönelik Tutum } & Erkek & 3,55 & 0,78 & \multirow{2}{*}{3,077} & \multirow{2}{*}{$0,002^{*}$} \\
\hline & Kadın & 3,33 & 0,70 & & \\
\hline
\end{tabular}

" $p<0,05$

Tablo 8'de katılımcların turizm gelişimine yönelik tutumlarının cinsiyet özelliğine göre karşılaştırılmasına ilişkin analiz sonuçlarına yer verilmiştir. Bu kapsamda araştırma katılımcılarının ekonomik, sosyal ve genel turizm gelişimine yönelik tutum alt boyutlarında cinsiyet özelliğine göre ayrılan gruplar arasında anlamlı düzeyde farklılık gösterdiği tespit edilmiştir $(\mathrm{p}<0,05)$. Dolayısıyla araştırma kapsamında oluşturulmuş " $\mathrm{H}_{1}$ : Yerel halkın turizm gelişimine yönelik tutum düzeylerine ilişkin görüşleri cinsiyet özelliğine göre anlamlı bir farklılık gösterir" hipotezi kabul edilmiştir. Bu çerçevede elde edilen sonuçlara göre cinsiyet özelliklerine göre ayrılan gruplardan erkek olan katılımcıların kadın olan katılımcılara göre ekonomik, sosyal ve genel turizm gelişimine yönelik tutum açısından, anlamlı düzeyde daha fazla turizm gelişimine yönelik tutum gösterdikleri tespit edilmiştir.

Tablo 9. Yerel Halkın Turizm Gelişimine Yönelik Tutumunun Yaş Özelliklerine Göre Karşılaştırılması (Anova Testi)

\begin{tabular}{|c|c|c|c|c|c|c|}
\hline Temel Değişken & Yaş & $\bar{X}$ & s.s. & f & $\mathrm{p}$ & Tukey \\
\hline \multirow{5}{*}{ Ekonomik } & 25 ve alt1 ${ }^{a}$ & 3,55 & 0,83 & \multirow{5}{*}{3,759} & \multirow{5}{*}{$0,011^{*}$} & \multirow[t]{5}{*}{ b-c } \\
\hline & $26-35^{b}$ & 3,73 & 0,79 & & & \\
\hline & $36-45^{c}$ & 3,23 & 1,01 & & & \\
\hline & $46-55^{d}$ & 3,81 & 0,56 & & & \\
\hline & 56 ve üzerie & 0 & 0 & & & \\
\hline \multirow{5}{*}{ Sosyal } & 25 ve alt $1^{\mathrm{a}}$ & 3,34 & 0,87 & \multirow{5}{*}{1,004} & \multirow{5}{*}{0,391} & \\
\hline & $26-35^{b}$ & 3,24 & 0,56 & & & \\
\hline & $36-45^{c}$ & 3,14 & 0,90 & & & \\
\hline & $46-55^{d}$ & 3,41 & 0,56 & & & \\
\hline & 56 ve üzerie & 0 & 0 & & & \\
\hline \multirow{5}{*}{ Çevresel } & 25 ve alt1 $^{\text {a }}$ & 3,48 & 0,90 & \multirow{5}{*}{1,641} & \multirow{5}{*}{0,179} & \\
\hline & $26-35^{b}$ & 3,37 & 0,58 & & & \\
\hline & $36-45^{c}$ & 3,20 & 0,74 & & & \\
\hline & $46-55^{\mathrm{d}}$ & 3,43 & 0,40 & & & \\
\hline & 56 ve üzerie & 0 & 0 & & & \\
\hline \multirow{5}{*}{$\begin{array}{c}\text { Genel Turizm Gelişimine Yönelik } \\
\text { Tutum }\end{array}$} & 25 ve alt1 ${ }^{a}$ & 3,46 & 0,78 & \multirow{5}{*}{1,994} & \multirow{5}{*}{1,114} & \\
\hline & $26-35^{b}$ & 3,49 & 0,57 & & & \\
\hline & $36-45^{c}$ & 3,19 & 0,82 & & & \\
\hline & $46-55^{d}$ & 3,59 & 0,46 & & & \\
\hline & 56 ve üzerie & 0 & 0 & & & \\
\hline
\end{tabular}

${ }^{*} \mathrm{p}<0,05 ; \mathrm{a}, \mathrm{b}, \mathrm{c}, \mathrm{d}, \mathrm{e}$, Her bir yöntem için farklı harfleri içeren gruplar arasındaki fark önemlidir. 
Tablo 9'da katılımcıların turizm gelişimine yönelik tutumlarının yaş özelliğine göre karşılaştırılmasına yönelik bağımsız örneklemler için tek faktörlü varyans analizi ve gruplar arasındaki farkı belirleyebilmek için tukey testi sonuçları yer almaktadır. Bu kapsamda araştırma katılımcılarının sadece ekonomik alt boyutta yaş özelliğine göre ayrılan gruplar arasında anlamlı düzeyde farklılık gösterdiği tespit edilmiştir $(p<0,05)$. Dolayısıyla araştırma kapsamında oluşturulmuş “ $\mathrm{H}_{2}$ : Yerel halkın turizm gelişimine yönelik tutum düzeylerine ilişkin görüşleri yaş özelliğine göre anlamlı bir farklılık gösterir" hipotezi kısmen kabul edilmiştir. Yaş özelliğine göre ayrılan gruplardan "26-35 arası" yaş grubundaki katılımcıların, "36-45 arası" yaş grubundaki katılımcılara göre ekonomik alt boyut açısından, anlamlı düzeyde daha fazla turizm gelişimine yönelik tutuma sahip oldukları görülmüştür.

Tablo 10. Yerel Halkın Turizm Gelişimine Yönelik Tutumunun Eğitim Durumu Özelliklerine Göre Karşılaştırılması (Anova Testi)

\begin{tabular}{|c|c|c|c|c|c|c|}
\hline Temel Değişken & Eğitim durumu & $\overline{\mathrm{X}}$ & s.s. & $\mathrm{f}$ & p & Tukey \\
\hline \multirow{5}{*}{ Ekonomik } & İlköğretima & 3,50 & 1,10 & \multirow{5}{*}{5,771} & \multirow{5}{*}{$0,000^{*}$} & \multirow[t]{5}{*}{ b-d } \\
\hline & Lise $^{b}$ & 3,38 & 0,91 & & & \\
\hline & Önlisansc & 3,59 & 0,70 & & & \\
\hline & Lisans $^{\mathrm{d}}$ & 3,82 & 0,65 & & & \\
\hline & Lisansüstüe $^{\mathrm{e}}$ & 3,64 & 0,54 & & & \\
\hline \multirow{5}{*}{ Sosyal } & İlköğretima & 3,31 & 0,90 & \multirow{5}{*}{2,914} & \multirow{5}{*}{$0,021^{*}$} & \multirow[t]{5}{*}{ b-d } \\
\hline & Lise $^{b}$ & 3,21 & 0,90 & & & \\
\hline & Önlisans ${ }^{c}$ & 3,22 & 0,72 & & & \\
\hline & Lisans $^{d}$ & 3,49 & 0,69 & & & \\
\hline & Lisansüstüe $^{\mathrm{e}}$ & 3,05 & 0,42 & & & \\
\hline \multirow{5}{*}{ Çevresel } & İlköğretima & 3,50 & 0,86 & \multirow{5}{*}{4,287} & \multirow{5}{*}{$0,002^{*}$} & \multirow[t]{5}{*}{ b-d } \\
\hline & Lise $^{\mathrm{b}}$ & 3,28 & 0,80 & & & \\
\hline & Önlisansc & 3,47 & 0,87 & & & \\
\hline & Lisans $^{\mathrm{d}}$ & 3,64 & 0,79 & & & \\
\hline & Lisansüstüe & 3,20 & 0,61 & & & \\
\hline \multirow{5}{*}{$\begin{array}{l}\text { Genel Turizm Gelişimine } \\
\text { Yönelik Tutum }\end{array}$} & İlköğretima & 3,43 & 0,89 & \multirow{5}{*}{5,147} & \multirow{5}{*}{$0,000^{*}$} & \multirow[t]{5}{*}{ b-d } \\
\hline & Lise $^{b}$ & 3,30 & 0,80 & & & \\
\hline & Önlisans ${ }^{c}$ & 3,44 & 0,66 & & & \\
\hline & Lisans $^{\mathrm{d}}$ & 3,67 & 0,61 & & & \\
\hline & Lisansüstü̈ & 3,35 & 0,47 & & & \\
\hline
\end{tabular}

${ }^{*} \mathrm{p}<0,05 ; \mathrm{a}, \mathrm{b}, \mathrm{c}, \mathrm{d}, \mathrm{e}, \mathrm{Her}$ bir yöntem için farklı harfleri içeren gruplar arasındaki fark önemlidir.

Tablo 10'da katılımcıların turizm gelişimine yönelik tutumlarının eğitim durumu özelliğine göre karşılaştırılmasına yönelik bağımsız örneklemler için tek faktörlü varyans analizi ve gruplar arasındaki farkı belirleyebilmek için tukey testi sonuçları yer almaktadır. Bu kapsamda araştırma katılımcılarının turizm gelişimine yönelik tutumunun tüm alt boyutlarda eğitim durumu özelliğe göre ayrılan gruplar arasında anlamlı düzeyde farklılık gösterdiği tespit edilmiştir $(\mathrm{p}<0,05)$. Dolayısıyla araştırma kapsamında oluşturulmuş " $\mathrm{H}_{3}$ : Yerel halkın turizm gelişimine yönelik tutum düzeylerine ilişkin görüşleri eğitim durumu özelliğine göre anlamlı bir farklılık gösterir" hipotezi kabul edilmiştir. Eğitim özelliğine göre ayrılan gruplardan lisans eğitim seviyesine sahip katılımcı gruplarının lise eğitim seviyesine sahip katılımcı grubuna göre tüm alt boyutlar 
açısından, anlamlı düzeyde daha fazla turizm gelişimine yönelik olumlu tutuma sahip olduğu görülmüştür.

Tablo 11. Yerel Halkın Turizm Gelişimine Yönelik Tutumunun Meslek Özelliklerine Göre Karşılaştırılması (Anova Testi)

\begin{tabular}{|c|c|c|c|c|c|c|}
\hline Temel Değişken & Meslek & $\overline{\bar{X}}$ & s.s. & $f$ & $p$ & Tukey \\
\hline \multirow{8}{*}{ Ekonomik } & Öğrenci a & 3,53 & 0,82 & \multirow{8}{*}{1,820} & \multirow{8}{*}{0,082} & \\
\hline & Ev Hanım ${ }^{b}$ & 3,25 & 0,67 & & & \\
\hline & Esnaf c & 3,63 & 0,97 & & & \\
\hline & $\begin{array}{l}\text { Devlet Memuru } \\
\text { d }\end{array}$ & 3,95 & 0,77 & & & \\
\hline & Çiftçi e & 3,50 & 1,07 & & & \\
\hline & İşçi ${ }^{f}$ & 3,58 & 0,97 & & & \\
\hline & İşsiz g & 3,57 & 0,59 & & & \\
\hline & Diğer $\mathrm{h}$ & 3,43 & 0,89 & & & \\
\hline \multirow{8}{*}{ Sosyal } & Öğrenci a & 3,26 & 0,87 & \multirow{8}{*}{1,823} & \multirow{8}{*}{0,081} & \\
\hline & Ev Hanımı $b$ & 3,02 & 0,58 & & & \\
\hline & Esnaf c & 3,34 & 0,87 & & & \\
\hline & $\begin{array}{l}\text { Devlet Memuru } \\
\text { d }\end{array}$ & 3,64 & 0,75 & & & \\
\hline & Çiftçi e & 3,36 & 1,03 & & & \\
\hline & İşçi ${ }^{f}$ & 3,29 & 0,92 & & & \\
\hline & İşsiz $\mathrm{g}$ & 3,17 & 0,49 & & & \\
\hline & Diğer $\mathrm{h}$ & 3,49 & 0,61 & & & \\
\hline \multirow{8}{*}{ Çevresel } & Öğrenci a & 3,46 & 0,92 & \multirow{8}{*}{2,199} & \multirow{8}{*}{$0,033^{*}$} & $d-b$ \\
\hline & Ev Hanımı ${ }^{b}$ & 3,22 & 0,51 & & & d-g \\
\hline & Esnaf c & 3,56 & 0,75 & & & d-h \\
\hline & $\begin{array}{l}\text { Devlet Memuru } \\
\mathrm{d}\end{array}$ & 3,76 & 0,72 & & & \\
\hline & Çiftçi ${ }^{\mathrm{e}}$ & 3,20 & 0,77 & & & \\
\hline & İşçi ${ }^{f}$ & 3,45 & 0,87 & & & \\
\hline & İşsiz g & 3,21 & 0,61 & & & \\
\hline & Diğer h & 3,20 & 0,60 & & & \\
\hline \multirow{8}{*}{$\begin{array}{l}\text { Genel Turizm Gelişimine } \\
\text { Yönelik Tutum }\end{array}$} & Öğrenci a & 3,42 & 0,79 & \multirow{8}{*}{1,887} & \multirow{8}{*}{0,070} & \\
\hline & Ev Hanım ${ }^{b}$ & 3,17 & 0,54 & & & \\
\hline & Esnaf c & 3,52 & 0,78 & & & \\
\hline & $\begin{array}{l}\text { Devlet Memuru } \\
\mathrm{d}\end{array}$ & 3,81 & 0,68 & & & \\
\hline & Çiftçi e & 3,38 & 0,91 & & & \\
\hline & İşçi ${ }^{\mathrm{f}}$ & 3,45 & 0,85 & & & \\
\hline & İşsiz $\mathrm{g}$ & 3,36 & 0,50 & & & \\
\hline & Diğer $\mathrm{h}$ & 3,40 & 0,58 & & & \\
\hline
\end{tabular}

${ }^{*} \mathrm{p}<0,05 ; \mathrm{a}, \mathrm{b}, \mathrm{c}, \mathrm{d}, \mathrm{e}, \mathrm{f}, \mathrm{g}$, Her bir yöntem için farklı harfleri içeren gruplar arasındaki fark önemlidir. 
Tablo 11'de katılımcıların turizm gelişimine yönelik tutumlarının meslek özelliğine göre karşılaştırılmasına ilişkin bağımsız örneklemler için tek faktörlü varyans analizi ve gruplar arasındaki farkı belirleyebilmek için tukey testi sonuçları yer almaktadır. Bu kapsamda araştırma katılımcılarının sadece çevresel alt boyutta meslek özelliğine göre ayrılan gruplar arasında anlamlı düzeyde farklılık gösterdiği tespit edilmiştir $(p<0,05)$. Dolayısıyla araştırma kapsamında oluşturulmuş “ $\mathrm{H}_{4}$ : Yerel halkın turizm gelişimine yönelik tutum düzeylerine ilişkin görüşleri meslek özelliğine göre anlamlı bir farklılık gösterir" hipotezi kısmen kabul edilmiştir. Meslek özelliğine göre ayrılan gruplardan devlet memuru mesleğine sahip katılımcı gruplarının ev hanımı, işsiz ve diğer meslek grubu katılımcılarına göre, çevresel alt boyutta, anlamlı düzeyde daha fazla turizm gelişimine yönelik tutuma sahip olduğu görülmüştür.

Tablo 12. Yerel Halkın Turizm Gelişimine Yönelik Tutumunun Aylık Gelir Özelliklerine Göre Karşılaştırılması (Anova Testi)

\begin{tabular}{|c|c|c|c|c|c|c|}
\hline Temel Değişken & Aylık Gelir & $\overline{\bar{X}}$ & s.s. & $\mathrm{f}$ & p & Tukey \\
\hline \multirow{6}{*}{ Ekonomik } & 1000TL ve alt1 & 3,41 & 0,79 & \multirow{6}{*}{4,552} & \multirow{6}{*}{$0,000^{*}$} & $a-c$ \\
\hline & $1001-2000 \mathrm{TL}^{\mathrm{b}}$ & 3,50 & 0,83 & & & a-e \\
\hline & $2001-3000 \mathrm{TL}^{\mathrm{c}}$ & 3,87 & 0,77 & & & \\
\hline & 3001-4000TLd & 3,65 & 0,82 & & & \\
\hline & 4001-5000TLe & 3,86 & 0,92 & & & \\
\hline & Gelirim yok ${ }^{\mathrm{f}}$ & 3,50 & 1,00 & & & \\
\hline \multirow{6}{*}{ Sosyal } & 1000TL ve altia & 3,22 & 0,81 & \multirow{6}{*}{3,174} & \multirow{6}{*}{$0,008^{*}$} & b-c \\
\hline & $1001-2000 \mathrm{TL}^{\mathrm{b}}$ & 3,02 & 0,73 & & & b-e \\
\hline & $2001-3000 \mathrm{TL}^{\mathrm{c}}$ & 3,50 & 0,76 & & & \\
\hline & $3001-4000 \mathrm{TL}^{\mathrm{d}}$ & 3,38 & 0,76 & & & \\
\hline & $4001-5000 \mathrm{TL}^{\mathrm{e}}$ & 3,54 & 0,85 & & & \\
\hline & Gelirim yok ${ }^{\mathrm{f}}$ & 3,40 & 0,92 & & & \\
\hline \multirow{6}{*}{ Çevresel } & 1000TL ve altia & 3,39 & 0,84 & \multirow{6}{*}{1,879} & \multirow{6}{*}{0,097} & \\
\hline & $1001-2000 \mathrm{TL}^{\mathrm{b}}$ & 3,18 & 0,63 & & & \\
\hline & $2001-3000 \mathrm{TL}^{\mathrm{c}}$ & 3,61 & 0,81 & & & \\
\hline & $3001-4000 \mathrm{TL}^{\mathrm{d}}$ & 3,38 & 0,67 & & & \\
\hline & $4001-5000 \mathrm{TL}^{\mathrm{e}}$ & 3,61 & 0,87 & & & \\
\hline & Gelirim yok $^{\mathrm{f}}$ & 3,42 & 0,88 & & & \\
\hline \multirow{6}{*}{$\begin{array}{l}\text { Genel Turizm Gelişimine } \\
\text { Yönelik Tutum }\end{array}$} & 1000TL ve alta & 3,34 & 0,73 & \multirow{6}{*}{3,803} & \multirow{6}{*}{$0,002^{*}$} & a-c \\
\hline & $1001-2000 \mathrm{TL}^{\mathrm{b}}$ & 3,27 & 0,63 & & & a-e \\
\hline & $2001-3000 \mathrm{TL}^{\mathrm{c}}$ & 3,69 & 0,71 & & & \\
\hline & $3001-4000 \mathrm{TL}^{\mathrm{d}}$ & 3,50 & 0,68 & & & \\
\hline & $4001-5000 \mathrm{TL}^{\mathrm{e}}$ & 3,70 & 0,82 & & & \\
\hline & Gelirim yok ${ }^{\mathrm{f}}$ & 3,45 & 0,85 & & & \\
\hline
\end{tabular}

${ }^{*} \mathrm{p}<0,05 ; \mathrm{a}, \mathrm{b}, \mathrm{c}, \mathrm{d}, \mathrm{e}, \mathrm{f}, \mathrm{g}$, Her bir yöntem için farklı harfleri içeren gruplar arasındaki fark önemlidir.

Tablo 12'de katılımcların turizm gelişimine yönelik tutumlarının aylık gelir özelliğine göre karşılaştırılmasına yönelik bağımsız örneklemler için tek faktörlü varyans analizi ve gruplar arasındaki farkı belirleyebilmek için tukey testi sonuçları yer almaktadır. Bu kapsamda araştırma katılımcılarının ekonomik, sosyal ve genel turizm gelişimine yönelik tutum alt boyutlarında aylık gelir özelliğine göre ayrılan gruplar arasında anlamlı düzeyde farklılık gösterdiği tespit edilmiştir 
$(\mathrm{p}<0,05)$. Dolayısıyla araştırma kapsamında oluşturulmuş " $\mathrm{H}_{5}$ : Yerel halkın turizm gelişimine yönelik tutum düzeylerine ilişkin görüşleri aylık gelir özelliğine göre anlamlı bir farklılık gösterir" hipotezi kabul edilmiştir. Aylık gelir özelliğine göre ayrılan grupların ekonomik ve genel turizm gelişimine yönelik tutum alt boyutlarında "2001-3000 TL arası" ve "4001-5000 TL arası" aylık gelir özelliğine sahip katılımcı gruplarının "1000 TL ve altı" aylık gelir özelliğine sahip katılımcı gruplarından anlamlı düzeyde olumlu tutum gösterdikleri görülmüştür.

\section{SONUÇ}

Turizmin olumlu ve olumsuz olarak yaşadığı değişimlerden en çok etkilenecek olan, bölgede yaşayan toplumdur. Bu nedenle yerel halkın turizm gelişimine yönelik tutumu önem arz etmektedir. Turizm potansiyeline sahip, gelişmekte olan veya gelişmiş turizm alanlarının yerel halk üzerindeki etkilerinin bilinmesi bölgedeki turizm gelişimi bakımından oldukça önemlidir (Ersoy, 2017). Kitle iletişimine dair yapılacak her türlü araştırma ve çalışmalarda karşılaşılacak sorunlara bilinçli bir yaklaşım sağlayabilmek önemlidir. Bu durum her şeyden önce kişi ya da onun içinde bulunduğu sosyal ortamın sahip olduğu, tutum ve algının gerçekte nelere bağlı olarak oluştuğu, örgütlendiği ve neye yaradığının bilinmesiyle mümkündür. Dolayısıyla bireyin, içinde yaşadığı dünya ile nasıl bir uyum sağladığını kavrayabilmek, önerilen değişikliklere katılabilmesinin nelere bağlı olduğunu anlamak, belirlenen işleri yapabilmeyi kolaylaştıracaktır.

Bu çalışmada yerel halkın turizm gelişimine yönelik tutumuna yönelik bir araştırma yapılmıştır. Çalışmanın sorunsalı ile ilgili olarak yapılan araştırmalar göz önüne alındığında farklı destinasyonlarda ve farklı değişkenlerle olan ilişki, etki düzeylerinin araştırıldığı görülürken, söz konusu bu destinasyonda incelemelerin yetersiz olduğu görülmüştür. Turizm gelişiminin önemli etkileyicilerinden biri olarak görülen yerel halkın turizm gelişimine yönelik tutumunun düzeyinin ve bireysel olarak farklılıkların belirlenmesinin gerektiği düşünülmektedir. Bu açıdan çalışmanın sonuçlarının yerel yöneticilerinin, sektör yöneticileri ve ilgili paydaşların turizm gelişimine yönelik yapacakları eylemler ve gelecekte yapılacak çalışmalara önemli oranda katkı sağlayacağı düşünülmektedir. Bu noktadan hareketle Çorum Il'inde yaşayan yerel halkın turizm gelişimine yönelik mevcut tutum düzeylerinin belirlenmesi ve bireysel özelliklerine yönelik nasıl farklılaştı̆̆ını belirlemek amacıyla Çorum'da yaşayan yerel halktan 424 kişinin görüşleri analiz edilmiştir.

Bu kapsamda araştırmanın temel amacına yönelik olarak, yerel halkın turizm gelişimine yönelik tutumunun belirlenmesi için gerçekleştirilen analizlerde katılımcıların, yüksek düzeyde turizm gelişimine yönelik olumlu tutuma sahip olduğu görülmüştür. Bu bulgudan hareketle turizm gelişimine yönelik olarak yerel halkın potansiyel pozitif bir tutumu olduğu ifade edilebilir. Ayrıca araştırma kapsamında elde edilen bulgulara göre, bireysel özelliklerine göre oluşan gruplar arasında anlamlı düzeyde farklılıkların olduğu tespit edilmiştir. Turizm gelişimine yönelik tutumun medeni durum ve ikamet süresi özelliği haricinde cinsiyet, yaş, eğitim durumu meslek, aylık gelir gibi bireysel özelliklere göre oluşan gruplar arasında anlamlı farklılıklar gösterdiği tespit edilmiştir. Nitekim Snaith ve Haley (1999) turizmin gelişmesinde önemli bir etki oluşturan yerel halkın turizm ve yönetimi ile ilgili görüşlerinin sosyo-ekonomik ve demografik göstergeler açısından önemli derecede farklılık gösterebileceğini belirtmektedir. Yine benzer şekilde çeşitli demografik özellikler açısından turizm gelişimi üzerinde farklı tutumların sergilendiğini ortaya koyan çalışmalar bulunmaktadır (Güneş ve Alagöz, 2018; Erkılıç, 2019; Türker ve Türker, 2014).

Turizm bölge ekonomisine önemli katkılar sağlamaktadır. Ancak bölgenin ya da yerel halkın turizmden faydalanabilmesi için öncelikle, yatırım ve tanıtım faaliyetlerinin yapılması 
gerekmektedir. Böylelikle turizmden sağlanan gelir sayesinde, alt ve üst yapı olanakları da gelişim gösterebilmekte ve yerel halkın turizm gelişimine yönelik olumlu tutumu daha da artabilmektedir. Öte taraftan ise turizmin olumsuz etkilerinin en aza indirilmesi gerekmektedir.

Turizmin en temel unsurlarından birinin doğal alanlar olduğu düşünüldüğünde, bu alanların daha iyi korunması ve özellikle de çevre kirliliğinin önüne geçilmesi üzerinde durulması gereken önemli konulardan biridir. Bu bakımdan turizm faaliyetleri bir yönüyle çevre üzerinde olumsuz etkiler bırakabilmektedir. Bu etkiler yerel halkın turizm gelişimine yönelik tutumunu olumsuz yönde etkileyebilir. Yanı sıra turizmin gelişmesiyle birlikte, tarihi değerlerin, mimarinin, kültürün vb. gibi birçok unsurun değeri daha çok anlaşılmaktadır. Böylelikle yerel halk bu tür değerlere daha çok önem verebilmekte ve turizme veya turizmin gelişimine yönelik daha olumlu tutum sergileyebilmektedir.

Yerel anlamda turizmin ekonomik ve çevresel etkilerinin yanında sosyo-kültürel etkilerinden de söz etmek mümkün olmaktadır. Yerel halkın sahip olduğu kültürel özellikler başlı başına önemli bir çekicilik unsuru oluşturabilmektedir. Diğer yandan ise turizm sayesinde yerel halk yeni insanlarla ve kültürlerle karşılaşabilmektedir. Bu konuda önemli olan nokta ise kültürel çatışmanın olmamasına ve yerel halkın kültürünün ticarileşmemesine dikkat edilmesidir. Nitekim turizm, sosyo-kültürel açıdan bölgelerin gelişimine ve tanıtımına önemli katkılar yapabilmektedir. Böylelikle bölgesel anlamda hem sürdürülebilir bir turizm faaliyeti gerçekleşmekte hem de bilinçli bir tutumun gelişmesiyle bu faaliyetin temelinde yer alan sosyokültürel çekicilikler özünü koruyabilmektedir.

Araştırma kapsamında elde edilen bilgilerden ve yapılan analiz sonuçlarından hareketle birtakım önerilerde bulunmak mümkündür. Çorum'da ikamet eden yerel halkın turizmin gelişimi konusunda ortaya çıkan olumu ve olumsuz tutumlarına yönelik kamu kurumları ve sivil toplum kuruluşları tarafından bilinçlendirici eğitimler verilebilir. Yerel halka turizmin sadece ekonomik faydaları değil, sosyo-kültürel ve çevresel faydaları konusunda da bilinçlendirme çalışmaları gerçekleştirilebilir. Turizm faaliyetlerinin bölgede devam ettiği sürece yerli halka önemli faydalar sağlayacağı bilinci aktarılması gerekmektedir. Yerel yönetimlerin turizm ile ilgili faaliyetlerde yerel halkı da dahil etmesi turizmin gelişmesi açısından önemli bir konudur. Tarihi değerlerin ve kültür varlıklarının koruma tedbirlerinin alınması sürdürülebilir turizm gelişimi açısından gereklidir. Turizm amaçlı yapılaşmaların bölgesel mimariye uygun olması gerekmektedir. Alt ve üst yapı olanaklarının geliştirilmesi ve çevre tahribatının azaltılması planlı bir turizm gelişimi açısından gereklidir. Genel olarak değerlendirildiğinde önerilerin dikkate alınması Çorum iline yönelik turizmin gelişmesi ve olumlu etkilerin arttırılması açısından faydalı olabilir.

\section{KAYNAKÇA}

Altıntaş, V. (2010). Turizmin gelişminin yerel halkın yaşam kalitesi üzerine etkileri: Alanya modeli örneği, Yayınlanmamış Doktora Tezi, Akdeniz Üniversitesi, Antalya.

Altunışık, R., Coşkun, R., Bayraktaroğlu, S. ve Yıldırım, E. (2012). Sosyal Bilimlerde Araştırma Yöntemleri: SPSS Uygulamal, Sakarya: Sakarya Yayıncilık.

Butler, R. W. (1980). The concept of tourism area cycle of evolution: Implications for management of resources, Canada Geographer, 24(1), 5-12.

Çakır, O. and Kodaş, B. (2020). Residents' Perceptions of Tourism Potential and Its Effect on Supporting Tourism Development: The Case of Çorum Province, GSI Journals Serie A: Advancements in Tourism, Recreation and Sports Sciences (ATRSS), 3 (1): 1-16. 
Dal, N. (2008). Kuşadası'nda kıyı kullanımı ve turizmin çevresel etkileri üzerine yerel halkın tutumları, Yayınlanmamış Yüksek Lisans Tezi, Adnan Menderes Üniversitesi, Aydın.

Değerliyurt, M., Aksu, R., Aydoğmuş, M. Y., Kaya, M. F. ve Türkmen, E. (2013). Diyarbakır kültür turizmine ilişkin coğrafya öğretmen adaylarının bakış açılarının belirlenmesi, Turkish Studies, 8(9), 1045-1057.

Demir, C. ve Çevirgen, A. (2006). Turizm ve Çevre Yönetimi, Ankara: Nobel Yayın Dağıtım.

Dinçer, M Z., Yozcu, S. ve Gedik, S. (2015). Turizmde Temel Kavramlar. İçinde Akova, O., Kızılırmak, İ. ve Tanrıverdi, H. (Ed.), Turizm İşletmeciliği (pp.301-332), Ankara: Detay Yayıncılık.

Doğan, H. Z. (2004). Turizmin Sosyo-Kültürel Temelleri, Ankara: Detay Yayıncllı.

Dyer, P. G. (2007). Structural modelling of resident perceptions of tourism and associated development on the sunshine coast, Australia, Tourism Management, 28, 409-422.

Erkılıç, E. (2019). Yerel halkın turizm algısı ve turizmin gelişimine yönelik tutumları: Rize örneği. International Journal of Contemporary Tourism Research, 3(1), 66-82.

Ersoy, H. (2017). Turizmin gelişiminin yerel halk üzerine sosyo-kültürel etkileri: Manavgat örneği, Yayınlanmamış Doktora Tezi, İzmir Kâtip Çelebi Üniversitesi, İzmir.

George, D. and Mallery, P. (2010). SPSS For Windows Step by Step: A Simple Study Guide and Reference. MA United States: Allyn and Bacon, Inc. A Viacom Company 160 Gould Street Needham Heights.

Gursoy, D., Ouyang, Z., Nunkoo, R. and Wei, W. (2019). Residents' impact perceptions of and attitudes towards tourism development: A meta-analysis. Journal of Hospitality Marketing $\mathcal{E}$ Management, 28(3), 306-333.

Güneş, E. ve Alagöz, G. (2018). Yerel halkın turizm algısı: Erzincan'da bir araştırma, Iğdır Üni. Sos. Bil. Dergisi, 15, 409-442.

Harrill, R. (2004). Residents' attitudes toward tourism development: A literature review with implications for tourism planning, Journal of Planning Literature, 18(3), 252-266.

İnceoğlu, M. (2010). Tutum, Algı, İletişim, Ankara: Beykent Üniversitesi Yayınları.

Jamal, T. B. and Getz, D. (1995). Collaboration theory and community tourism planning, Annals of Tourism Research, 22(1), 186-204.

Judd, C. M., Smith, E. R., and Kidder, L. H. (1991). Research Methods in Social Science, Fort Worth: Holt, Rinehart and Wanston.

Kahraman, N. ve Türkay, O. (2012). Turizm ve Çevre (Gözden Geçirilmiş 5. Baskl), Ankara: Detay Yayıncilik. 
Kim, H. S. (2002). We Talk, Therefore we think? A cultural analysis of the effect of talking on thinking, Journal of Personality and Social Pyschology, 83(4), 828-842.

Kozak N, Akoğlan Kozak, M. ve Kozak, M. (2017). Genel Turizm, Ankara: Detay Yayıncılık.

Lee, T. H. (2013). Influence analysis of community resident support for sustainable tourism development, Tourism Management, 34, 37-46.

Lickorish, L. J. and Jenkins, C. L. (1997). An Introduction to Tourism, Oxford: Elsevier ButterworthHeinemann Linacre House, Jordan Hill.

Nunkoo, T. and Ramkissoon, H. (2007). Resident perceptions of the socio-cultural impact of tourism in Mauritus, Anatolia an International Journal of Tourism and Hospitality Research, 18(1): 138144.

Özdemir, M. A. ve Kervankıran, İ. (2011). Turizm ve turizmin etkileri konusunda yerel halkın yaklaşımlarının belirlenmesi: Afyonkarahisar örneği, Marmara Coğrafya Dergisi, 24, 1-25.

Ramkissoon, H., and Nunkoo, R. (2011). City image and perceived tourism impact: Evidence from Port Louis, Mauritius, International Journal of Hospitality \& Tourism Administration, 12(2), 123-143.

Ratz, T. (2000). The social-cultural impact of tourism case of lake balaton research support scheme, Research Support Scheme, Virtus.

Roney Akış, S. (2011). Turizm: Bir Sistemin Analizi, Ankara: Detay Yayıncılık.

Ryan, C. (2003). Recreational Tourism: Demand and Impact, Great Britain: Channel View Publications.

Sabuncuoğlu, Z. ve Vergiliel Tüz, M. (2016). Örgütsel Davranış, Bursa: Alfa Aktüel Basım.

Snaith, T. and Haley, A. (1999). Residents' opinions of tourism development in the historic city of York, England. Tourism Management, 20(5), 595-603.

Stylidis, D., Biran, A., Sit, J. and Szivas, E. M. (2014). Residents' support for tourism development: The role of residents' place image and perceived tourism impacts, Tourism Management, 45, 260274.

Türker, G. Ö., ve Türker, A. (2014). Yerel halkın turizm etkilerini algılama düzeyi turizm desteğini nasıl etkiler: Dalyan destinasyonu örneği. Ejovoc (Electronic Journal of Vocational Colleges), 4(1), 8198. 